\title{
Digital Information Literacy Among Research Scholars and Students Community At Dravidian University, Kuppam-Andra Pradesh (India): An Exploratory Study
}

\author{
Dr.M.ANJAIAH, Assistant Professor \\ Dept. of Library and Information Science, Dravidian University-KUPPAM
}

\begin{abstract}
Digital Literacy (DL) is the process of teaching and learning about technology and the use of technology. It is the ability to use information and communication technologies to find, evaluate, create, and communicate information, requiring both cognitive and technical skills. The ability to understand and use information in multiple formats from a wide range of sources when it is presented via computers. The present paper highlights that A majority of the respondents $62(63.26 \%)$ were male, A majority $62(63.28 \%)$ respondents having PCs, Laptops, Smart Phones and Tabs, A majority $47(47.95 \%)$ of the professional respondents were using the internet, A majority $102(81.60 \%)$ of the respondents were known about the digital information, majority of the respondents $66(67.34 \%)$ were hails from villages, followed by $19.38 \%$ respondents from mandals, A majority $85(86.73 \%)$ of the respondents visiting the library to borrow the library e-books which is a good sign to use, A large majority $92(93.87 \%)$ of the respondents are facing frequently power off, followed by $85(88.77 \%)$ respondents facing wi-fi problems while browsing the digital resources at hostel premises.
\end{abstract}

Key Words: Information Literacy, ICT, Digital Literacy, Internet, Google, Wi-Fi

\section{INTRODUCTION:}

With the advent of globalization in the realm of education, there has been information explosion. The present decade has been dubbled as the information age. The internet boom in India has become one of the major contributors to the economic growth of the country. The use of internet has increased more than 11 times in the last seven years. This rise has led to the growth of cybercafés and internet parlors throughout India with easy accessibility and cost effective services helped by the enhanced speed of the internet.

The library and information landscape has transformed with the onset of the digital era and today traditional libraries have changed their roles to serve as 'Knowledge Centers' with priority on value added electronic information services. Digital Literacy is the awareness, attitude and ability of individuals of appropriately use digital tools and facilities to identify access, manage, integrate, analyze the digital resources and create media. Literacy includes the ability to read and interpret media, to reproduce data and images through digital manipulation, and to evaluate and apply new knowledge gained from digital environments.

Digital Literacy (DL) is the process of teaching and learning about technology and the use of technology. It is the ability to use information and communication technologies to find, evaluate, create, and communicate information, requiring both cognitive and technical skills. The ability to use digital technology, communication tools or networks to locate, evaluate, use and create information. The ability to understand and use information in multiple formats from a wide range of sources when it is presented via computers.

A person's ability to perform tasks effectively in a digital environment Digitally Literate individuals find meaning in and make use of digital information, they exhibit the characteristics of cultural and social understanding, collaboration, the ability to find and select information, effective communication, E-safety, functional skills, creativity, and critical thinking. Digital information is a symbolic representation of data, and literacy refers to the ability to read for knowledge, write coherently, and think critically about the written word.

Meaning of Digital Literacy (DL): Digital Literacy is the awareness, attitude and ability of individuals of appropriately use digital tools and facilities to identify access, manage, integrate, analyze the digital resources and create media. 


\section{Definitions of Digital Literacy (DL):}

1. According to Paul Glister, DL is the ability to understand information and more important- to evaluate and integrate information in multiple format that the computer can deliver. Being able to evaluate and interpret information is critical you cannot understand information you find on the internet without evaluating its sources and placing.

2. Digital literacy is the knowledge, skills used in a broad range of digital devices such as smart phones, tablets, laptops and desktop PCs, all of which are seen as network rather than computing devices.

The Concept of Digital Literacy: The Concept of Digital Literacy (DL) is about mastering ideas, not keystrokes," distinguishing digital literacy from a more limited technical skills view. "The term was introduced by Paul Gilster in his book "Digital Literacy" (Gilster, 1997). Not only must you acquire the skill of finding things, you must also acquire the ability to use these things in your life" (pp. 1-2). He suggested four core competencies of internet searching, hypertext navigation, knowledge assembly, and content evaluation.

Types of Literacy: The following types of literacy are discussed below:

1. Information Literacy: According to National Forum on Information Literacy, "The ability to know when there is a need for information, to be able to identify, locate, evaluate, and effectively use that information for the issue or problem at hand."

2. Computer Literacy: Computer literacy preceded digital literacy, and refers to knowledge and skills in using traditional computers (such as desktop PCs and laptops) with a focus on practical skills in using software application packages.

3. Digital Literacy: Digital Literacy is the ability to use information and communication technologies to find, evaluate, create, and communicate information, requiring both cognitive and technical skills.

4. Media Literacy: Media Literacy when individuals retrieve, assemble and evaluate media. It rests on the use of tools present in technology literacy and is intertwined with the interpretation and creation of images in visual literacy.

The Characteristics of Digital Literacy: Bawden, followed in 2001 with a specified list of characteristics or skills associated with the idea of digital literacy:

- Awareness of "people networks" as sources of advice and help

- Knowledge Assembly or building a "reliable information hoard" from diverse sources

- Retrieval Skills, plus "critical thinking" for making informed judgments about retrieved information, with wariness about the validity and completeness of internet sources

- Reading and Understanding Non-Sequential and Dynamic Material

- Using Filters and Agents to Manage Incoming Information.

- Information literacy as the construct that incorporates all the different kinds of literacy, digital literacy in providing individuals with online reading and understanding abilities.

Review of Related Literature: Literature Review enables us to gain a comprehensive overview and summary of the available information on a particular topic. Literature reviews are generally more useful to all practitioners than any one individual piece of research because they allow one piece of research to be viewed within the wider context of others. The literature on Digital Information Literacy among the Research Scholars and Students Community at Dravidian University, Kuppam-Andra Pradesh: a Study a hot topic for research.

1. Ray and Day (1998) carried out a study on students attitudes towards electronic resources. The study reveals that a large number of students leave universities without necessary skills to cope within the information based society. Electronic information resources offers today's student new opportunities that were not available to previous generations.

2. The study by Harris (2013) looks at the concept of 'Digital Libraries', and the collections and services of digital libraries, in comparison to 'traditional libraries'. The brief history of the idea of digital libraries, and a discussion about digital library is explained. The remainder of their study report examines the differences between digital libraries and traditional libraries with regard collections and services offered.

3. Clegg and Carey (1997) summarize the practical work, examining the impact on the users of information technology. There have been efforts in the academic community to move from a paper-based classroom to a paperless classroom. Adams and Janson (1997) focus on the information technology and tell how it supports the model of learning in a particular situation. They mainly focus on how the information technology enhances learning

4. Rockman (2003) states that, libraries should plan ahead and take their services to where users require most rather than becoming too limited or denying users the chance to learn in modern environment using virtual reference service. 
5. Shuling (2007), in his study stated that the electronic information has gradually become a major resource in all libraries. The emergence of electronic information resources, simply referred to as electronic resources, has tremendously transformed information handling and management in academic environments and in University libraries in particular.

6. Ellis and Oldman (2005) note that through the use of electronic resources, researchers and students; now have access to global information resources, particularly the Internet for their scholarly intercourse.

7. Joinson and Banyard (2002) in their 'user-study' on engineering undergraduate students is made by Majid and Tan (2002). This study investigates the information needs and information seeking behaviour of computer engineering students of Nayang Technological University, Singapore. This study reveals that the types of information sources used by the students are more in the electronic format. The importance of and reasons for using certain electronic information sources are investigated by the authors. The students are now very comfortable in using web resources and they want more resources through web enabled technology.

8. Bilal (2002) reports the key findings of the information seeking behavior and success of students in using the web. The students'behaviour and success were compared in his study. The study reveals that the use of search engine and the level of research skills are directly proportional to their success.

\section{University Library-A Profile:}

The Dravidian University was established by the Government of Andhra Pradesh through a Legislature Act no. 17 of 1997 at Kuppam, Andra Pradesh, a tri-Lingual junction in the South-Western Part of Andhra Pradesh to promote Dravidian languages and research. The University Library was also started in 1997 with a small collection of books. The Library located in Narayanaguru Bhavan- called as Bishop-Caldwell Dravidian E-Resources Centre. Presently, there is a rich collection on various academic courses. At present, the total collection is 78, 546 by April, 2016.

\section{Digital Library:}

For the benefit of the students, research scholars and staff of Dravidian University, the digital library facility has been provided to update their knowledge and to utilize the electronic information which is available in the library. The Digital Library (DL) will be function from 10.00 AM to 8.00 PM.Presently, 150 users are browsing the digital resources such as e- Journals, e-books, and subject related materials and other resources for a day.

Objectives: The following specific objectives were made for the present study:

1. To know the importance of the information communication technologies in library and information centers in the digital era.

2. To examine the digital literacy among the research scholars and student community

3. To know the knowledge of research scholars and student community on digital information resources

4. To know the users knowledge on using of the smart-phones, tabs, desk top computers and laptops.

5. To know purpose of visiting the library

6. To identify the problems faced by the research scholars and student community while browsing the digital information resources

7. To give suitable suggestions for more utilizing the digital information resources.

Hypotheses: The following the hypotheses were made for the present study:

1. The research scholars and students were known about the digital information

2. The digital resources are very much useful to research scholars and students for their quality of education

3. The ICT equipments like smart phones, tabs, desk top computers and laptops known by the respondents

4. The digital information resources are very much useful to the research scholars and student community for study and research.

Methodology: For the present study, the survey method is adopted. The data is collected through a structured questionnaire. Attitude scales are used to measure the user attitudes. Relevant statistical methods are employed for analysis, interpretation and presentation of the data. The entire statistical analysis was done using MS office Excel. 
Analysis of data: Statistical Techniques for analyzing the collected data from the respondents, the simple percentages and tables are used.

Table 1: Distribution of Questionnaires

\begin{tabular}{|c|l|c|c|}
\hline S.no. & \multicolumn{1}{|c|}{$\begin{array}{c}\text { Nature of the } \\
\text { Respondents }\end{array}$} & $\begin{array}{c}\text { Total No. of } \\
\text { Questionnaires Distributed }\end{array}$ & $\begin{array}{c}\text { Total No. of } \\
\text { Questionnaires Received }\end{array}$ \\
\hline 1 & $\begin{array}{l}\text { Post-Graduate } \\
\text { Students (PG) }\end{array}$ & $50(33.33)$ & $28(21.33 \%)$ \\
\hline 2 & $\begin{array}{l}\text { Under- Gradates } \\
\text { Students (UG) }\end{array}$ & $100(66.66)$ & $70(44.00 \%)$ \\
\hline 3 & Total & $150(100.00)$ & $98(65.33)$ \\
\hline
\end{tabular}

The above table (No.1) reveals that a total of $\mathbf{1 5 0}$ questionnaires were randomly distributed to research scholars and students of Dravidian University covering all the disciplines and $\mathbf{9 8}$ filled questionnaires were received. The response rate is $\mathbf{6 5 . 3 3 \%}$.

Table- 2: Gender-Wise Distribution of the Respondents

\begin{tabular}{|c|l|c|c|}
\hline S. no. & Nature of Respondents & No. of Respondents & Percentage \\
\hline 1 & Male & 62 & 63.26 \\
\hline 2 & Female & 36 & 36.74 \\
\hline 3 & Total & 98 & 100.00 \\
\hline
\end{tabular}

The above table (2) indicates that out of a total of 98 respondents, majority of the respondents $62(63.26 \%)$ were male, followed by $33(36.74 \%)$ of the respondents were female. It shows that a majority of the respondents were male.

Residential status of the Respondents: The data pertaining to the nature of residence of the respondents as to whether they are urbanites or ruralities has been collected and the same is presented in below table.

Table 3: Residential Status of the Respondents

\begin{tabular}{|c|l|c|c|}
\hline S. no. & \multicolumn{1}{|c|}{ Status of the Residency } & No. of Respondents & Percentage \\
\hline 1 & Village & 66 & 67.34 \\
\hline 2 & Mandal & 19 & 19.38 \\
\hline 3 & City & 13 & 13.26 \\
\hline 4. & Total & 98 & 100.00 \\
\hline
\end{tabular}

From the above table (No.3), it is clear that majority of the respondents $66(67.34 \%)$ were hails from villages, followed by $19.38 \%$ respondents from mandals and remaining from city $13(13.26 \%)$. This shows that village students are giving much importance to digital information resources. This is a healthy sign that the rural people are now recognizing the importance of education and are showing very much interest to knowing the importance digital resources.

Age Group of the Respondents: It was attempted to find out that the age groups of the respondents who were utilizing the e- resources from the university library for their study. The data collected for this purpose has been presented in the below table 5.

Table-4: Age-Wise Group of the Respondents

\begin{tabular}{|c|l|c|c|}
\hline S. no. & \multicolumn{1}{|c|}{ Age Group } & No. of Respondents & Percentage \\
\hline 1 & $18-22$ & 70 & 71.42 \\
\hline 2 & $23-27$ & 15 & 15.30 \\
\hline 3 & $28-32$ & 11 & 11.22 \\
\hline 4 & 33 and above & 02 & 2.04 \\
\hline 5. & Grand Total & 98 & 100.00 \\
\hline
\end{tabular}


A perusal at the above table reveals that majority of the respondents i.e., 70 (71.42 per cent) are in the younger age group of 18-22 years. About 15.30 per cent students are of the age group of 23-27 years. It is also found that only i.e. 02 (2.04 per cent) respondents are in the age group of 33 years and above. It is to pertinent to that the age group between 18-22 students were pursuing the higher education. It is higher than the other developing nations in the world (UNESC Annual Report-2013).

Knowledge on Digital Information Literacy: A research question has put to the respondents for digital information/resources which are available on internet. The respondents opinions were discussed in the below.

Table 5: Knowledge on Digital Information Literacy

\begin{tabular}{|c|l|c|c|c|}
\hline S.no. & Status of Respondents & Yes & No & Total \\
\hline 1 & Research Scholars & $25(20.00)$ & $03(2.4)$ & $28(22.4 \%)$ \\
\hline 2 & Student Community & $77(61.6)$ & $20(20.00)$ & $97(77.6 \%)$ \\
\hline 3 & Total & $102(81.6)$ & $23(18.4)$ & $125(100.00)$ \\
\hline
\end{tabular}

The above table (5) explains that a majority $102(81.60 \%)$ of the respondents were known about the digital information. Among them, a large majority of the student community $77(61.60 \%)$ were very well known about the digital information, followed by the research scholars $25(20.00 \%)$ were also known about the digital information literacy. It is further found that both research scholars and students are very much acquainted with ICT skills. It is a good sign.

Knowledge on Availability on Digital Information Resources: A research question has been put to the respondents for knowledge on availability of digital information resources. They replied and the same information is discussed below table.5.

Table 6: Knowledge on Using Desk Top PCs/Smart Phones/Laptops/Tabs

\begin{tabular}{|c|l|c|c|c|}
\hline S.no. & \multicolumn{1}{|c|}{$\begin{array}{c}\text { Nature of ICT } \\
\text { Equipments }\end{array}$} & Research Scholars & Students Community & Total \\
\hline 1 & Smart Phones/Tabs & $32(32.65 \%)$ & $22(22.44 \%)$ & $54(55.10 \%$ \\
\hline 2 & Desktops/Tabs & $18(18.36 \%)$ & $36(36.73)$ & $44(44.90 \%)$ \\
\hline 3 & Total & $40(40.81 \%)$ & $58(59.19 \%)$ & $98(100.00 \%)$ \\
\hline
\end{tabular}

The above table (No.6) reveals that a total of 98 respondents, a majority $54(55.10 \%)$ respondents having the smart phones and tabs, followed by $44(44.90 \%)$ respondents having their PC- Desktops/Tabs. It shows that majority of respondents having personal Smart Phones, Tabs and PC-Desktops which is a good healthy for getting digital information resources.

Table 7: Having PCs/ Laptops//Smart Phones/Tabs

\begin{tabular}{|l|l|l|l|l|}
\hline S. no. & Nature of Equipments & Yes & \multicolumn{1}{|c|}{ No } & \multicolumn{1}{c|}{ Total } \\
\hline 1 & Desk Top PC \& Laptops & $19(19.38 \%)$ & $08(8.16 \%)$ & $27(27.56 \%)$ \\
\hline 2 & Smart Phones/Tabs & $43(43.87 \%)$ & $28(28.57 \%)$ & $71(72.44 \%)$ \\
\hline 3 & Total & $62(63.28 \%)$ & $36(36.73 \%)$ & $98(100.00 \%)$ \\
\hline
\end{tabular}

Data presented in the above table on PCs, Laptops, Smart Phones and Tabs, Out of 98 respondents, a majority 62 (63.28 \%) respondents having PCs, Laptops, Smart Phones and Tabs and remaining 36 (36.73 \%) respondents do not have PCs, Laptops, Smart Phones. It shows that majority respondents having ICT equipments. It is also a good sign. This shows that research scholars as well as student community knows well about digital literacy skills.

Table 8: Frequency of Visiting the Digital Library

\begin{tabular}{|c|l|c|c|}
\hline S.no. & Visiting the Digital Library & No. of Respondents & Percentage \\
\hline 1 & Daily & 45 & 45.91 \\
\hline 2 & Once in a Week & 22 & 22.44 \\
\hline 3 & Fortnightly & 16 & 16.32 \\
\hline 4 & Monthly & 15 & 15.30 \\
\hline 5. & Total & 98 & 100.00 \\
\hline
\end{tabular}


The above table 8 explains about the frequency of visiting the university library. Out of 98 , A majority $45(45.91 \%)$ respondents are visiting the university library daily, followed by 22(22.44\%) respondents visit the library once in a week, $16(16.32 \%)$ respondents were visiting library fortnightly and $15(15.30 \%)$ respondents monthly visits the library. It is pertinent to note that a large majority of the respondents were visiting the university digital library daily for digital information resources for their academic use.

Purpose of Visiting the Library: The students are visiting the university library to use the library material and use of digital/Internet resources for their study and research to gain good academic achievements.

Table 9: Purpose of Visiting the University Library

\begin{tabular}{|c|l|c|c|}
\hline S.no & \multicolumn{1}{|c|}{ Purpose of Browsing } & No. of Respondents & Percentage \\
\hline 1 & Borrowing the e-books & 85 & 86.73 \\
\hline 2 & E-Journals & 61 & 62.24 \\
\hline 3 & E-Referenence Material & 54 & 55.10 \\
\hline 4 & Reading the E-News Papers & 78 & 79.59 \\
\hline 5. & Filling the Online Applications & 75 & 76.53 \\
\hline 6 & E-mails/Chatting/Social Sites & 65 & 66.32 \\
\hline 7 & Downloading the Course Material & 59 & 60.20 \\
\hline 8 & Viewing/downloading Movies & 16 & 16.32 \\
\hline 9 & Visiting the web sites & 32 & 32.65 \\
\hline 10 & Looking for advertisement & 68 & 69.38 \\
\hline
\end{tabular}

The above table (9) explicit that the purpose of visiting the university library. They were asked multiple answers for obtaining the digital resources. A majority $85(86.73 \%)$ of the respondents visiting the library to borrow the library e-books which is a good sign to use, 75 (76.53\%) respondents were visiting for browsing for digital resources for more useful of their study, a majority of the respondents $68(69.38 \%)$ for looking the employment advertisements, followed by $61(62.24 \%)$ respondents for reading the News Paper reading, 75 $(76.53 \%)$ respondents for applying jobs/filling the online applications, 65 (66.32\%) respondents for viewing the E-mails/Chatting/Social Sites to share information with others via social net works and for visiting web sites $32.65 \%, 55.10 \%$ for getting the reading materials and $16.32 \%$ of the respondents for entertainment through movies. On the whole, majority of the respondents visiting the library purposively. It is also a good sign.

Table 10: Location of Internet Browsing

\begin{tabular}{|c|l|c|c|}
\hline S.no. & \multicolumn{1}{|c|}{ Place of Browsing } & No. of Respondents & Percentage \\
\hline 1 & Digital Library & 58 & 59.18 \\
\hline 2 & Department & 13 & 13.26 \\
\hline 3 & Computer Center & 11 & 11.22 \\
\hline 4 & Cyber Café & 13 & 13.26 \\
\hline 5 & Home & 03 & 3.06 \\
\hline 6 & Total & 98 & 100.00 \\
\hline
\end{tabular}

The above table (10) reveals that the location of the internet. Out of 98 respondents, majority 58 $(59.18 \%)$ respondents browsing internet from the digital library for getting required e-resources for their academic need, followed by $13(13.26 \%)$ respondents browsing internet from Cyber Café and Departments equally, $11(11.22 \%)$ from Computer Center and $3(3.06 \%)$ respondents were browsing the internet from their home. It shows that the importance of the digital information in university library which is more conveniently to the students community as well as research scholars for their use.

Table 11: Awareness on Internet

\begin{tabular}{|c|l|c|c|}
\hline S. no. & \multicolumn{1}{|c|}{ Status of Respondents } & No. of Respondents & Percentage \\
\hline 1 & Professionals & 47 & 47.95 \\
\hline 2 & Non-Professionals & 51 & 52.04 \\
\hline 3 & Total & 98 & 100.00 \\
\hline
\end{tabular}

The above table (11) showed awareness of respondents on using the Internet. Out of 98 respondents, 47 $(47.95 \%)$ professional respondents were using the internet while non-professionals respondents 51 (52.04\%) were more using the internet It shows that the Non-Professionals were using the Internet. 
Table 12: Accessing the Digital Information Resources

\begin{tabular}{|c|l|c|c|}
\hline S.no. & \multicolumn{1}{|c|}{ Nature of the E-Resources } & No. of Respondents & Percentage \\
\hline 1 & E-Books & 17 & 17.34 \\
\hline 2 & Open Access Journals(Online) & 18 & 18.36 \\
\hline 3 & E-Databases & 05 & 5.10 \\
\hline 4 & E-Conference Proceedings & 03 & 3.06 \\
\hline 5 & UGC-Infornet E-Journals & 04 & 4.08 \\
\hline 6 & Wikipedia/Internet Resources & 51 & 52.04 \\
\hline 7 & Total & 98 & 100.00 \\
\hline
\end{tabular}

The above table (No. 11) explains about the E-resources which are availble on the net/web. Out of 98 respondents, off-of-the respondents $51(52.04 \%)$ were using wikipedia, $18(18.36 \%)$ respondents were using the Open Access Journals, followed by 17 (17.34\%) respondents using E-Books, E-databases 5(5.10\%) using by respondents, $4(4.08 \%)$ and $3(3.06 \%)$ respondents were using the E-Conference Proccdings and UGC-Infonet E-Journals for their regular study.

Problems Faced by the Respondents: The respondents are facing many problems while browsing the Internet e-resources in the library. Their opinions were presented in the following table no. 13

Table 13: Problems Faced by the Respondents

\begin{tabular}{|l|c|c|}
\hline \multicolumn{1}{|c|}{ Nature of Problems } & No. of Respondents & Percentage \\
\hline Wi-fi Problems ( Hostels premises) & 85 & 88.77 \\
\hline While browsing Digital Resources & 54 & 55.10 \\
\hline Slow of Internet Access Speed & 67 & 68.36 \\
\hline Frequently Power Off & 92 & 93.87 \\
\hline Limited Computer Terminals & 81 & 82.65 \\
\hline Digital Library Timings -Not- Sufficient & 78 & 79.59 \\
\hline
\end{tabular}

(Note: Open -Ended Multiple Answers asked)

The above table (12) reveals that the problems faced by the respondents while browsing. A large majority 92 $(93.87 \%)$ of the respondents are facing frequently power off, followed by $85(88.77 \%)$ respondents facing wi-fi problems while browsing the digital resources at hostel premises, $81(82.65 \%)$ respondents were said that about the limited computer terminals in the library,78 (79.59\%)of the respondents were opined that the digital library timings, On the whole, the respondents were facing many problems while browsing digital resources.

\section{Level of Satisfaction:}

The user satisfaction is most important for any library. It all depends upon the identification of users need and fulfillment their requirements. Hence, the users were requested to indicate their level of satisfaction towards the digital information resources. A question has been put to the respondents to know the satisfaction of users on the availability of digital resources in the library. The replies are analyzed and presented in the given table 14

Table 14: Satisfaction on the Digital Information Resources

\begin{tabular}{|l|c|c|}
\hline \multicolumn{1}{|c|}{ Satisfaction of the Respondents } & Total No. of Respondents & $\begin{array}{c}\text { Percentag } \\
\mathrm{e}\end{array}$ \\
\hline Fully Satisfied & 30 & 30.61 \\
\hline Partially Satisfied & 47 & 47.95 \\
\hline Not Satisfied & 21 & 21.42 \\
\hline Total & 98 & 100.00 \\
\hline
\end{tabular}

The above table (14) shows that the majority $30(30.61 \%)$ of the respondents were fully satisfied with the digital information resources, followed by $47(21.42 \%)$ respondents were partially satisfied with the eresources, $21(21.42 \%)$ respondents not satisfied with the existing availability of digital e-resources. It is clear from the above table that the digital resources are very useful, needful to the students and also research scholars for quality of research. 


\section{CONCLUSION}

Digital technology provide new opportunities for students and educators to pursue their interests and find educational resources, experiences and courses any time and any place. Digital Literacy (DL) is the process of teaching and learning about technology and the use of technology. It is the ability to use information and communication technologies to find, evaluate, create, and communicate information, requiring both cognitive and technical skills. The ability to use digital technology, communication tools or networks to locate, evaluate, use and create information. The ability to understand and use information in multiple formats from a wide range of sources when it is presented via computers. Digital literacy is distinct from computer literacy and digital skills. Computer literacy preceded digital literacy, and refers to knowledge and skills in using traditional computers (such as desktop PCs and laptops) with a focus on practical skills in using software application packages. Digital skills is a more contemporary term but is limited to practical abilities in using digital devices such as laptops and smart phones.

Suggestions: For the benefit of research scholars and students, the following some of the important suggestions were made:

1. The university authorities should be taken some immediate steps for wi-fi connection with high bandwidth in the entire university campus.

2. The university digital library should be strengthened with enhancing the computer terminals.

3. Some steps should be taken to overcome the frequent power off.

4. More digital information resources should be provided.

5. E-books, e-Journals and other e-course material should be acquired and provided by the library, which is also very needful to the students to use in their study and research academic activities.

6. There is urgent need to conduct the user awareness programmes such as on-hand workshop-cum- training programmes and user education programmes on using digital information resources which are most useful for study and research.

\section{REFERENCES:}

[1] Anjaiah,M.(2014).Digital Information Literacy Skills Among Users in Public Libraries: A Case Study of District Central Library, Warangal District, A.P., In B.Ramesh Babu and Others (eds) Role of Library Associations in Promoting Information Literacy in the Knowledge Society, APLA, Vijayawada, pp.327334

[2] Barbara R. Jones-Kavalier and Suzanne L. Flannigan: Connecting the Digital Dots: Literacy of the 21st Century; Bawden, D. (2001). Information and digital literacies: a review of concepts. Journal of Documentation, 57(2), 218-259.

[3] Bawden, D. (2008). Origins and Concepts of Digital Literacy. Digital literacies: concepts, policies and practices, 17-32.

[4] Carroll, J. (2013, June). Engaging and authentic technology use for literacy learning in the middle years. Literacy Learning: The Middle Years, 21 (2), 7-17.

[5] Ellis,D.Oldman,H (2005) The English literature researcher in the age of Internet",Journal of Information Science Vol.31 No. 1

[6] Gilster, P. (Ed.). (2006). Digital fusion: defining the intersection of content and communica- tions. In A. Martin \& D. Madigan (Eds.), Digital literacies for learning (pp. 42-50). London: Facet Publishing.

[7] Gilster, P. (1997). Digital literacy. New York: Wiley.56-65

[8] Harris, M. W. (2013). What's a digital library?. Retrieved July,24, 2013, from http://nextnexus.info/writing/infostudies/digital_libraries.php

[9] Joinson, A., \& Banyard, P. (2002). Psychological aspects of information seeking on the internet. ASLIB Proceedings, 54 (2), 95-102.

[10] Paul Gilster, Digital Literacy, New York: Wiley and Computer Publishing, 1997, p.1.

[11] Ray K. \& J. Day (1998) Student Attitudes towards Electronic Information Usage "Journal of Information Research" Vol. 4 No.2,17-23

[12] Rockman, I.F. (2001). Visionary pragmatism in an e-library environment. Reference Services Review, 29 (3), 169-170.

[13] Shuling, C. \& Wu.H. (2007), Investigation and Analysis of current use of electronic resources in University libraries. Library management. Vol.28 No. 1,2, 72-88

[14] Subba Rao, S. (1997). Information retrieval services: Role of optical technologies. New Library World, 98 (1132), 16-24. 